40th Anniversary

\title{
光合成光捕集系における電子エネルギー移動と量子コヒーレンス
}

\author{
石㠃 章仁 \\ 自然科学研究機構 分子科学研究所 ( $7444-8585$ 愛知県岡崎市明大寺町西郷中38番地)
}

\section{Electronic Energy Transfer and Quantum Coherence in Photosynthetic Light Harvesting}

\author{
Akihito ISHIZAKI \\ Institute for Molecular Science, National Institutes of Natural Sciences, 38 Nishigo-Naka, Myodaiji, Okazaki, Aichi 444-8585
}

(Received May 8, 2013)

\begin{abstract}
Recent two-dimensional electronic spectroscopic experiments revealed that electronic energy transfer in photosynthetic light harvesting involves long-lived quantum coherence among electronic excitations of pigments. These findings have led to the suggestion that quantum coherence might play a role in achieving the remarkable quantum efficiency of photosynthetic light harvesting. Further, this speculation has led to much effort being devoted to elucidation of the quantum mechanisms of the photosynthetic excitation energy transfer. In this review, we provide an overview of recent experimental and theoretical investigations of photosynthetic electronic energy transfer, specifically addressing the observed longlived coherence. We close with some thoughts on directions for future developments in this area.
\end{abstract}

Key Words: Photosynthetic light harvesting systems, Electronic excitation, Four-wave mixing, Twodimensional electronic spectroscopy, Quantum coherence

1. はじめに

光合成は太陽光の物理エネルギーを細胞が利用可能な 化学エネルギーに変換する分子過程であり, 糖の生成を 通して地球上のほぼ全ての生命活動を維持している。近 年は再生可能エネルギーの観点からも注目されエネル ギー資源問題に応える緊急課題として光合成機構の仕組 みを取り入れた分子素子の研究開発が進められている。 また, 近年の系外惑星探査や生命居住可能惑星の議論と 相まって光合成システムに注目が集まっている。

光合成は多くの素過程から構成される複雑な反応系で あり，特にその初期過程は

1) chlorophyllやbacteriochlorophyllなど色素分子による 光の吸収と電子励起

2) 光捕集系を構成する色素分子間での電子励起エネル ギー移動

3) 反応中心タンパク質に内包される色素分子による電 子励起エネルギーの捕集と所謂special pairと呼ばれ る2個の (bacterio) chlorophyll間での電荷分離反応 から成る ${ }^{1)}$. 興味深いことに, 反応中心タンパク質に内 包された色素分子の数や空間配置は緑色植物や種々の光 合成細菌の間で類似している。一方, 光捕集アンテナを 構成するタンパク質や内包される色素分子の数 ·空間配 置は生物種により異なりバラエティに富み ${ }^{1,2)}$ (具体的な
光捕集アンテナは, 文献1，2を参照されたい), 光エネ ルギーを捕集するだけで電荷分離反応を起こさない. し たがって, 色素分子間での電子励起エネルギー移動過程 が光合成の効率を決める重要な要素といえる。実際，太 陽光の強度が弱い場合には, 色素分子の光吸収によって 生じる電子励起エネルギーが反応中心において電荷分離 反応に用いられる量子収率はほぼ100\%である。少なく とも10個, 多い場合には100個以上の分子を経由する化 学反応過程としては極めて効率が良く, その分子機構・ 物理化学原理を理解することは未だチャレンジングな問 題として我々の前に立ちはだかっている。

電子励起エネルギー移動の物理化学的研究の題材とし て多く用いられてきた光合成生物として緑色硫黄細菌が ある。緑色植物や藍色細菌とは異なり, 緑色硫黄細菌は 水分解による酸素を発生させず, 硫化水素を電子供与体 として利用し硫黄粒を生じさせる. 緑色硫黄細菌はクロ ロソームと呼ばれる巨大な光捕集アンテナを持ち, クロ ロソームと反応中心タンパク質の間にFenna-MatthewsOlson(FMO) タンパク質と呼ばれる「エネルギー移動の ワイヤー」が存在する。このFMOタンパク質は, 三量体 として存在し各単量体には7個のbacteriochlorophyll $a$ $(\mathrm{BChl} a)$ 分子が内包されている。 その比較的小さな構造 ゆえに実験研究および理論研究の格好の対象として取り 上げられてきた2). 
2005年, 米国カリフォルニア大学バークレー校の Fleming率いるグループのBrixnerらは二次元電子分光法 と呼ばれる三次の非線形レーザー分光法を用いてFMO タンパク質における電子励起エネルギーの流れを解析 し, (1)FMOタンパク質には電子励起エネルギーの経路 が2本存在すること，(2)電子励起エネルギーは固有状態 のエネルギー準位の梯子を単純にカスケードするのでは なく量子力学的非局在化状態の空間的性質に依存してい ること，の2点を明らかにした Engelらは同じく二次元電子分光法を用いてFMOタンパ ク質中のBChl $a$ 分子の電子励起状態の固有状態間の量子 力学的重ね合わせ・量子コヒーレンスに由来すると考え られる量子ビートを観測した ${ }^{4)}$. 観測された量子ビート は少なくとも660フェムト秒もの寿命を持ち, 凝縮相中 では電子固有状態間の量子コヒーレンスは10-100フェ ムト秒程度で減衰すると考えられていたことから，寿命 の長さは驚きと懷疑をもって受け止められた。同様の長 寿命量子コヒーレンスは紅色細菌の反応中心 ${ }^{5,6)}$ やクリ プト藻7)などでも観測され，また，緑色植物で太陽光工 ネルギーを捕集するタンパク質Light-Harvesting Complex II (LHCII) からも観測された ${ }^{8,9)}$. 相次いで見出されたこ れら電子励起由来の長寿命量子コヒーレンスが光合成光 捕集の高い効率に何らかの役割を果たしているのではな いかという希望的観測が研究者の好奇心を刺激し欧米を 中心に大きな注目を集めた。

本稿では, 光合成光捕集系研究の最近の展開, とくに 二次元電子分光法によって明らかにされた電子励起エネ ルギー移動の様相について紹介したい.

\section{2. 光合成光捕集系}

\section{1 色素分子のモデリング}

光合成光捕集アンテナを構成する色素分子は多くの場 合, 酸素非発生型の光合成細菌ではバクテリアクロロ フィル (bacteriochlorophyll $a, \mathrm{BChl} a$ ) であり, 酸素発生型 の藍色細菌や緑色植物ではクロロフィル $a$ (chlorophyll $a$, $\mathrm{Chl} a)$ またはクロロフィル $b($ chlorophyll $b, \mathrm{Chl} b)$ である. クロロフィル, バクテリオクロロフィルともに, 大環状 л電子系を骨格として有しているため電子遷移に伴う吸 収帯が可視領域から近赤外領域にあり（青色から近紫外 領域を吸収するSoretバンド，赤色から近赤外領域を吸 収する $\mathrm{Q}_{\mathrm{x}}$ バンド・ $\mathrm{Q}_{\mathrm{y}}$ バンド) 太陽光を都合良く吸収する ことが可能となる ${ }^{1)}$ 。通常はHOMOからLUMOへの遷移 に相当する $\mathrm{Q}_{\mathrm{y}}$ バンドだけに着目し(バクテリオ)クロロ フィルは二準位系としてモデル化される。たとえば番号 $m$ でラベルされたクロロフィル $a(\mathrm{Chl} a \mathrm{~m})$ を電子基底状 態 $\left|\varphi_{m g}\right\rangle$ と電子励起状態 $\left|\varphi_{m e}\right\rangle$ の準位系と考える.

(バクテリオ)クロロフィルは中性分子であるため基底 状態にある間はお互いに相互作用しないが，いったんあ る(バクテリオ)クロロフィル $m$ が電子励起されるとその 電子状態の変化が近隣の基底状態にある(バクテリオ)ク ロロフィル $n$ の電子との相互作用を誘起する。 この相互 作用は(バクテリオ)クロロフィル $m$ と $n$ の遷移双極子 $\vec{\mu}_{m}$
と $\vec{\mu}_{n}$ の相互作用として近似的に表すことができる：

$$
\hbar J_{m n} \approx \frac{\vec{\mu}_{m} \cdot \vec{\mu}_{n}}{\left|\vec{R}_{m n}\right|^{3}}-3 \frac{\left(\vec{\mu}_{m} \cdot \vec{R}_{m n}\right)\left(\vec{\mu}_{n} \cdot \vec{R}_{m n}\right)}{\left|\vec{R}_{m n}\right|^{5}}
$$

ここで, $\vec{R}_{m n}$ は(バクテリオ)クロロフィル $m$ と $n$ の中を 繋ぐ幾何べクトルであり，（2.1）式の相互作用により(バ クテリオ)クロロフィル $m$ の電子励起が $n$ に移動する.

\section{2 色素タンパク質複合体のモデリング}

Fig. 1に示すように，光合成光捕集系において(バクテ リオ)クロロフィルはタンパク質に内包され, 色素タン パク質複合体 (pigment-protein complex: PPC) を形成す る. タンパク質に内包される色素分子の電子状態は周囲 のアミノ酸残基との静電相互作用により変化し，またそ れらの運動により色素分子の電子状態も時間的に摇ら ぐ. この変化・摇らぎの振幅は数十 $\mathrm{cm}^{-1}$ から数百 $\mathrm{cm}^{-1}$ と 小さく，電子・原子核の運動から現象を適切に再現する のは容易ではない.したがって，摇らぎを誘起する自由 度が多数あることに注意した現象論的モデルが用いられ ることが多い. (バクテリオ)クロロフィル $m$ の電子状態 $\left|\varphi_{m a}\right\rangle(a=g, e)$ の摇らぎを誘起するタンパク質環境の自 由度の座標をまとめて $X$ と表し, 電子状態 $\left|\varphi_{m a}\right\rangle$ のネル ギーを $E_{m a}(X)$ とする. (バクテリオ)クロロフィル $m$ の電 子状態の摇らぎはcollective energy gap coordinate, ${ }^{10,11)}$

$$
\hbar \Delta \omega_{m}(X)=E_{m e}(X)-E_{m g}(X)-\hbar \Omega_{m}
$$

で特徴付けられる。ここでれ $\Omega_{m}$ は(バクテリオ)クロロ フィル $m$ のタンパク質環境との相互作用のもとでの $\mathrm{Q}_{\mathrm{y}}$ バ ンドのFranck-Condonエネルギーである。このとき，色 素タンパク質複合体における電子励起エネルギー移動を 記述するハミルトニアンは

$H_{\mathrm{PPC}}=\sum_{m=1}^{N} \sum_{a=g, e}\left|\varphi_{m a}\right\rangle E_{m a}(X)\left\langle\varphi_{m a}\left|+\sum_{m, n}\right| \varphi_{m e}\right\rangle\left|\varphi_{n g}\right\rangle \hbar J_{m n}\left\langle\varphi_{m g}\right|\left\langle\varphi_{n e}\right|$

と表される ${ }^{11)}$. タンパク質環境が誘起する色素の電子状

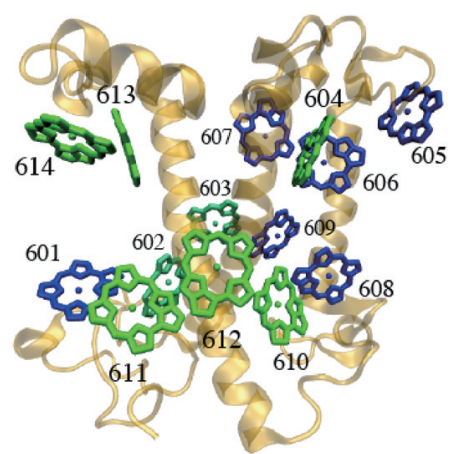

Fig. 1 The crystal structure of light-harvesting complex II (LHCII) isolated from spinach (PDB ID code 1RWT). The relative position of the chlorophylls (Chl $a$ in right gray and Chl $b$ in dark gray) is drawn with the $\alpha$-helices spanning the thylakoid membrane. The numbers (601-614) label individual chlorophylls. 
態・空間配置の摇らぎの為に色素間の相互作用 $J_{m n}$ も摇 らいでいるはずであるが，通常は $J_{m n}$ の摇らぎを無視す る近似が用いられる。光捕集タンパク質に結合した(バ クテリオ)クロロフィルの励起状態の自然放出による寿 命は一般に1ナノ秒程度であるので, フェムト秒ーピコ 秒程度の時間スケールを議論する限りに色素タンパク質 複合体内の励起の数は保存されると考えてよい. した がって，励起の数によってハミルトニアン (2.3) 式を分 解することができる，多くの場合，異なる（バクテリオ） クロロフィルの電子状態波動関数の空間的重なりは小さ く交換相互作用は無視してよいので積状態が導入でき る. 励起の数が 0 の場合の状態とハミルトニアンは

$$
|0\rangle \equiv \prod_{m}\left|\varphi_{m g}\right\rangle, \quad H_{\mathrm{PPC}}^{(0)}=E_{0}(X)|0\rangle\langle 0|
$$

で与えられる。ここで

$$
E_{0}(X)=\sum_{m=1}^{N} E_{m g}(X)
$$

を導入した．励起の数が 1 の状態：

$$
|m\rangle \equiv\left|\varphi_{m e}\right\rangle \prod_{k(\neq m)}\left|\varphi_{k g}\right\rangle
$$

に対してハミルトニアンは

$$
H_{\mathrm{PPC}}^{(1)}=\sum_{m=1}^{N} E_{m}(X)|m\rangle\left\langle m\left|+\sum_{m \neq n} \hbar J_{m n}\right| m\right\rangle\langle n|
$$

となる。ただし，右辺第2項 $E_{m}(X)$ は

$$
\begin{aligned}
E_{m}(X) & =E_{m e}(X)+\sum_{k(\neq m)} E_{k g}(X) \\
& =\hbar \Omega_{m}+\hbar \Delta \omega_{m}(X)+E_{0}(X)
\end{aligned}
$$

で与えられる。すなわち電子励起エネルギー移動は摇ら ぐエネルギー $E_{m}(X)$ のサト $|m\rangle$ から摇らぐエネルギー $E_{n}(X)$ のサイト $|n\rangle$ サホッピングとして理解される。晴 天時に緑色植物内の色素分子が吸収する太陽光フォトン の数は1秒間あたり約 10 個程度であるので ${ }^{1)}$, 天然の光 合成光捕集現象を議論するうえでは励起の数が 0 または 1 の場合を考えれば十分であるが, 複数のレーザーパルス を照射する非線形分光実験ではexcited state absorption (ESA)により励起の数が 2 にり得る。この場合には,

$$
|m, n\rangle \equiv\left|\varphi_{m e}\right\rangle\left|\varphi_{n e}\right\rangle \prod_{k(\neq m, n)}\left|\varphi_{k e}\right\rangle \quad(m \neq n)
$$

に対して(2.7) 式と同様のハミルトニアンが得られ $b^{12)}$.

\section{3 電子励起エネルギー移動とエキシトン}

(2.7), (2.8) 式において $J_{m n}$ の絶対值が $\Omega_{m}-\Omega_{n}$ や $\Delta \omega_{m}(X)$ の大きさより小さい場合, 電子励起エネルギー は各サイトに局在化しエネルギー移動はBrown運動のよ うな古典的拡散となる。他方, $J_{m n}$ の絶対值が比較的大 きい場合には電子励起は複数のサイト上に量子的に非局
在化し得る。この場合は (2.7)，（2.8)式を

$$
\begin{aligned}
H_{\mathrm{PPC}}^{(1)}= & \sum_{m=1}^{N} \hbar \Omega_{m}|m\rangle\left\langle m\left|+\sum_{m \neq n} \hbar J_{m n}\right| m\right\rangle\langle n| \\
& +\sum_{m=1}^{N} \hbar \Delta \omega_{m}(X)|m\rangle\langle m|+E_{0}(X)
\end{aligned}
$$

の形に摇らぎを含まない部分 (1行目) と含む部分 (2行目) に分離し，摇らぎを含まない部分の対角化が行われる：

$$
H_{\mathrm{PPC}}^{(1)}=\sum_{\mu=1}^{N} E_{\mu}\left|e_{\mu}\right\rangle\left\langle e_{\mu}\left|+\sum_{\mu, \nu} u_{\mu \nu}\right| e_{\mu}\right\rangle\left\langle e_{\nu}\right|+E_{0}(X)
$$

$\left|e_{\mu}\right\rangle$ はエネルギー固有值 $E_{\mu}$ に属する固有状態で複数のサ イト $\{|m\rangle\}$ の量子力学的重ね合わせ

$$
\left|e_{\mu}\right\rangle=\sum_{m=1}^{N} c_{\mu m}|m\rangle
$$

で表される. 光合成光捕集系研究の文脈では非局在エキ シトン (delocalized exciton) と呼ばれることが多い. (2.11) 式の右辺第2項はタンパク質環境との相互作用に よって誘起されるエキシトン・エネルギーの摇らぎ $(\mu=v)$ またはエキシトン間の遷移 $(\mu \neq v)$ を表す.

同様に，非線形分光実験で重要となる励起の数が2の 場合にもハミルトニアンは対角化され,

$$
\left|f_{\bar{\mu}}\right\rangle=\sum_{m, n} c_{\bar{\mu}(m n)}|m, n\rangle
$$

が得られる。本稿では, $e$ は励起の数が1の場合のエキシ トンに用い, $f$ と添字のバーは励起の数が 2 の場合に用い る.

\section{4 電子励起の量子コヒーレンス}

「コヒーレンス」という言葉は異なる分野の研究者が異 なる意味で語ることが多く，ともすれば定義が曖昧にな りがちである。議論の混乱がコヒーレンスの意味に起因 することも少なくない. ここでは先ず凝縮相化学動力学 の文脈で用いられる「コヒーレンス」の意味を明確にして おきたい.

超短レーザーパルスによる光励起では特定の電子エネ ルギー固有状態 (エキシトン状態)だけでなく, 複数の電 子エネルギー固有状態を同時に励起し, それらの線形結 合で表される非定常状態を生成することができる。例え ばレーザーパルスによってエキシトン $\left|e_{\alpha}\right\rangle$ と|$\left|e_{\beta}\right\rangle$ の線形 結合で表される状態が生成されたとする：

$$
|\Psi(t=0)\rangle=\frac{1}{\sqrt{2}}\left|e_{\alpha}\right\rangle+\frac{1}{\sqrt{2}}\left|e_{\beta}\right\rangle
$$

この状態はエネルギー固有状態ではないため, 時間とと もに変化する。ここでは簡単のため色素分子の電子励起 とタンパク質環境との相互作用を無視し時間発展が (2.10) 式1行目のハミルトニアンによるSchrödinger方程 式で記述できると仮定すると，(1)式の時間発展は次の ようになる： 
$|\Psi(t)\rangle=\frac{1}{\sqrt{2}} \exp \left(-E_{\alpha} t / \hbar\right)\left|e_{\alpha}\right\rangle+\frac{1}{\sqrt{2}} \exp \left(-E_{\beta} t / \hbar\right)\left|e_{\beta}\right\rangle$

このように, 状態べクトルが互いに明確な位相関係をも つ複数の固有状態の量子力学重ね合わせとして表される 場合を「固有状態間にコヒーレンスがある」と呼んでい る。（2.15）式を非線形光学応答の定式化で重要な役割を 果たす密度行列を用いて表現すると

$$
\begin{aligned}
|\Psi(t)\rangle\langle\Psi(t)|= & \frac{1}{2}\left|e_{\alpha}\right\rangle\left\langle e_{\alpha}\left|+\frac{1}{2}\right| e_{\beta}\right\rangle\left\langle e_{\beta}\right| \\
& +\frac{1}{2} \exp \left\{-i\left(E_{\alpha}-E_{\beta}\right) t / \hbar\right\}\left|e_{\alpha}\right\rangle\left\langle e_{\beta}\right|(2.16) \\
& +\frac{1}{2} \exp \left\{-i\left(E_{\beta}-E_{\alpha}\right) t / \hbar\right\}\left|e_{\beta}\right\rangle\left\langle e_{\alpha}\right|
\end{aligned}
$$

となり, コヒーレンスの存在はエネルギー固有值の差で 振動する密度行列の非対角成分として現れる.

いま, 二つの電子エネルギー固有状態が複数の色素の 電子励起を共有しているとする。 たとえば, Fig. 1に示 したLHCIIの中には次の非局在化エキシトン状態があ る $^{9)}$ :

$$
\begin{aligned}
\left|e_{1}\right\rangle=0.18|a 602\rangle & +0.18|a 610\rangle \\
& +0.45|a 611\rangle-0.65|a 612\rangle \\
\left|e_{6}\right\rangle=0.84|a 611\rangle & +0.53|a 612\rangle
\end{aligned}
$$

これらを(2.15) 式に代入することによりChla 611 とChla 612に電子励起が存在する確率として

$$
\begin{aligned}
& P_{a 611}(t) \propto 0.455+0.380 \cos \left[\left(E_{6}-E_{1}\right) t / \hbar\right] \\
& P_{a 612}(t) \propto 0.350-0.345 \cos \left[\left(E_{6}-E_{1}\right) t / \hbar\right]
\end{aligned}
$$

が得られ，電子励起をChla 611 またはChla 612に見いだ す確率が交互に入れ替わるように振動することが分か る。つまり，振動固有状態間のコヒーレンスが核波束振 動を意味するように ${ }^{13,14)}$, 非局在化エキシトン間のコ ヒーレンスの存在は色素電子励起の波束が空間を波打つ ように伝わる状態に対応する。このように位相をコヒー レントに保ちながら電子励起の波束がタンパク質内を移 動する様は「コヒーレントなエネルギー移動 (coherent energy transfer)」と呼ばれることもある。通常，このよう なエネルギー移動はタンパク質内部などの凝縮相で起こ り，(2.10)式2行目または (2.11) 式右辺第2項で表される 摇らぎ・散逸により量子力学的重ね合わせ・位相は乱さ れるので時間の経過に伴いコヒーレンスは消失する。一 方で, 従来のFörster理論で記述されるような摇らぎが支 配的となる拡散的なエネルギー移動は「インコヒーレン ト・ホッピング (incoherent hopping)」と呼ばれる ${ }^{11)}$.

\section{3. 二次元電子分光法}

高次非線形光学応答や二次元電子分光法の厳密な理論 展開や実験技術の詳細は他に譲り ${ }^{10,12)}$, 本稿では要点を 押さえるだけにとどめることにする。

\section{1 三次の非線形光学応答}

光合成光捕集系を構成する色素タンパク質複合体にお ける電子励起エネルギー移動の解析に用いられた二次元 電子分光法は，四光波混合に基づいた三次非線形分光法 の一つである。四光波混合では，次の形で現れる3個の パルス電場をサンプルに照射する：

$$
\boldsymbol{E}(t)=\sum_{j=1}^{3} \hat{\boldsymbol{E}}_{j} A_{j}\left(t-\tau_{j}\right) \exp \left\{-i \omega_{j}\left(t-\tau_{j}\right)+i \boldsymbol{k}_{j} \cdot \boldsymbol{r}\right\}+c . c .
$$

$j$ 番目のパルス電場の偏光は単位ベクトル $\hat{\boldsymbol{E}}_{j}$ で特徵付け られパルスの中心は時刻 $\tau_{j}\left(\tau_{1} \leq \tau_{2} \leq \tau_{3}\right)$ で表される. $A_{j}(t), \boldsymbol{k}_{j}, \omega_{j}$ はj番目のパルス電場の波形, 波数べクト ル, キャリア振動数である。このとき, サンプルには単 位体積あたり

$$
\begin{aligned}
\boldsymbol{P}^{(3)}(t)= & n_{\mathrm{PPC}} \int_{0}^{\infty} d t_{3} \int_{0}^{\infty} d t_{2} \int_{0}^{\infty} d t_{1} \vec{\Phi}\left(t_{3}, t_{2}, t_{1}\right) \\
& \times \boldsymbol{E}\left(t-t_{3}\right) \boldsymbol{E}\left(t-t_{3}-t_{2}\right) \boldsymbol{E}\left(t-t_{3}-t_{2}-t_{1}\right)
\end{aligned}
$$

で表される三次の分極が誘起され信号電場 $\boldsymbol{E}_{\mathrm{sig}}(t)=$ $i \boldsymbol{P}^{(3)}(t)$ が放射される。ここで $n_{\mathrm{PPC}}$ は測定対象の色素タン パク質複合体の数密度であり, $\vec{\Phi}\left(t_{3}, t_{2}, t_{1}\right)$ は三次の非線 形応答関数を表す四階テンソルである，四光波混合では ヘテロダイン信号を得るためにlocal oscillator(LO) と呼 ばれるレーザー電場 $\boldsymbol{E}_{\mathrm{LO}}(t)$ を加え，観測される信号は

$$
S=\int_{-\infty}^{\infty} d t \boldsymbol{E}_{\mathrm{LO}}^{*}(t) \cdot i \boldsymbol{P}^{(3)}(t)
$$

と表される，通常のphoton echo測定に基づく二次元電子 分光法では，(3.1) 式の入射電場に対して位相整合の方 向 $\boldsymbol{k}_{\mathrm{I}}=-\boldsymbol{k}_{1}+\boldsymbol{k}_{2}+\boldsymbol{k}_{3}$ (rephasing) と $\boldsymbol{k}_{\mathrm{II}}=\boldsymbol{k}_{1}-\boldsymbol{k}_{2}+\boldsymbol{k}_{3}$ (nonrephasing)の信号を用いる.

3.2 二次元電子分光法による量子コヒーレンスの解 析

電子励起の量子コヒーレンスの解析には $\boldsymbol{k}_{\mathrm{II}}=\boldsymbol{k}_{1}-$ $\boldsymbol{k}_{2}+\boldsymbol{k}_{3}$ の位相整合方向に放射されるnon-rephasing信号が より有用である。 Non-rephasing信号は近似的に次のよう に記述される ${ }^{18)}$ :

$$
\begin{aligned}
S_{\mathrm{NR}}\left(t_{3}, t_{2}, t_{1}\right) & \simeq \sum_{\alpha \beta} \mu_{0 \beta} G_{\beta 0}\left(t_{3}\right) \mu_{\beta 0} G_{00 \leftarrow 00}\left(t_{2}\right) \mu_{0 \alpha} G_{\alpha 0}\left(t_{1}\right) \mu_{\alpha 0} \rho_{00} \\
& +\sum_{\alpha \beta \gamma \delta} \mu_{0 \gamma} G_{\gamma 0}\left(t_{3}\right) \mu_{0 \delta} G_{\gamma \delta \leftarrow \alpha \beta}\left(t_{2}\right) \mu_{\beta 0} G_{\alpha 0}\left(t_{1}\right) \mu_{\alpha 0} \rho_{00} \\
& -\sum_{\alpha \beta \gamma \delta \bar{\varepsilon}} \mu_{\delta \bar{\varepsilon}} G_{\bar{\varepsilon} \delta}\left(t_{3}\right) \mu_{\bar{\varepsilon} \gamma} G_{\gamma \delta \leftarrow \alpha \beta}\left(t_{2}\right) \mu_{\beta 0} G_{\alpha 0}\left(t_{1}\right) \mu_{\alpha 0} \rho_{00}
\end{aligned}
$$

ここで，和は励起の数が1の場合のエキシトン(たとえば $\left.e_{\alpha}\right)$ と励起の数が2の場合のエキシトン $\left(\right.$ たとえば $\left.f_{\bar{\varepsilon}}\right)$ につ いて取る。 $\mu_{\alpha \beta}$ はエネルギー固有状態 $\alpha$ (たとえば $0, e_{\alpha}$, $\left.f_{\bar{\alpha}}\right)$ と $\beta\left(\right.$ たとえば0, $\left.e_{\beta}, f_{\bar{\beta}}\right)$ の間の遷移双極子であり, $G_{\delta \gamma \leftarrow \alpha \beta}(t)$ は密度演算子の時間発展 $\left(\right.$ たとえば $\left|e_{\delta}\right\rangle\left\langle e_{\gamma}\right| \leftarrow$ $\left.\left|e_{\alpha}\right\rangle\left\langle e_{\beta}\right|\right)$ を表す。ただし, $G_{\alpha \beta \leftarrow \alpha \beta}(t)$ は $G_{\alpha \beta}(t)$ と略記し 


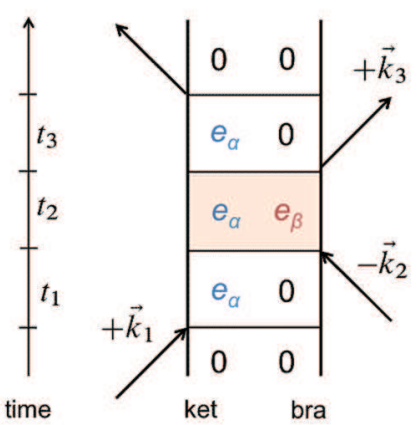

b

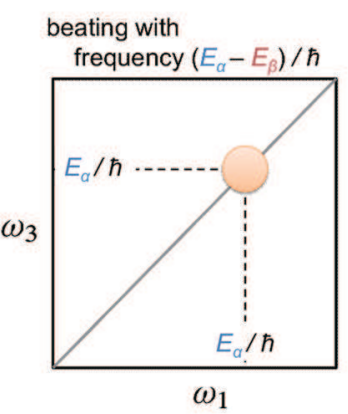

Fig. 2 (a) A double-sided Feynman diagram, which represent optical responses giving rise to quantum beats of $2 \mathrm{D}$ electronic spectra. In a double-sided Feynman diagram, the time evolution of the density matrix describing electronic excitation is represented by two gray vertical lines labeled ket and bra, where time runs vertically from bottom to top, and aslant arrows represent system-field interactions. 0 and $e_{\alpha}$ represent the overall ground state and an exciton state in the one-excitation manifold, respectively. In this diagram, the electronic system is prepared in a coherence state, $\left|e_{\alpha}\right\rangle\left\langle e_{\beta}\right|$, during the waiting period $t_{2}$. As shown in panel (b), this process is observed as the beating of a diagonal peak $\left(\omega_{1}, \omega_{3}\right)=\left(E_{\alpha}, E_{\alpha}\right) / \hbar$ in $2 \mathrm{D}$ nonrephasing spectrum with a frequency of $\left(E_{\alpha}-E_{\beta}\right) / \hbar$.

た.（3.4）式は一見煩雑であるので, double-sided Feynman diagramを用いるのが便利である。Fig. 2は(3.4) 式2行目，右辺第3項に含まれる項

$$
+\mu_{0 \alpha} G_{\alpha 0}\left(t_{3}\right) \mu_{0 \beta} G_{\alpha \beta \leftarrow \alpha \beta}\left(t_{2}\right) \mu_{\beta 0} G_{\alpha 0}\left(t_{1}\right) \mu_{\alpha 0} \rho_{00}
$$

に対応するdouble-sided Feynman diagramである。解釈は 次のようになされる。最初, 色素タンパク質複合体の電 子状態は基底状態にある: $\rho_{00}=|0\rangle\langle 0|$. 1 回目のレー ザーとの相互作用がケット $|0\rangle$ に作用し $\left|e_{\alpha}\right\rangle$ が生成し2回 目の相互作用までの時間 $t_{1}$ のあいだコヒーレントに時間 発展する: $e^{-E_{\alpha} t / \hbar}\left|e_{\alpha}\right\rangle\langle 0|$. 次に, 2 回目のレーザーとの相 互作用がブラ $\langle 0|$ を $\left\langle e_{\beta}\right|$ に励起し 3 回目の相互作用までの 時間 $t_{2}$ のあいた $e^{-\left(E_{\alpha}-E_{\beta}\right) t_{2} / \hbar}\left|e_{\alpha}\right\rangle\left\langle e_{\beta}\right|$ の形で時間発展する. 3 回目のレーザーとの相互作用以降は同様に解釈される.

(3.4) 式2行目，右辺第3項に含まれる項

$$
-\mu_{\beta \bar{\varepsilon}} G_{\bar{\varepsilon} \beta}\left(t_{3}\right) \mu_{\bar{\varepsilon} \alpha} G_{\alpha \beta \leftarrow \alpha \beta}\left(t_{2}\right) \mu_{\beta 0} G_{\alpha 0}\left(t_{1}\right) \mu_{\alpha 0} \rho_{00}
$$

に対応するdouble-sided Feynman diagramもFig. 3に示し た. 3回目のレーザーとの相互作用によりエキシトン $\left|e_{\alpha}\right\rangle$ が更に励起され励起の数が2の場合のエキシトン $\left|f_{\gamma}\right\rangle$ が生成されている。 また, double-sided Feynman diagram においてブラに作用するレーザーパルスが奇数回の場 合，(3.4) 式の項にマイナスの符号がつくことに注意さ れたい ${ }^{10,12)}$.

一般に二次元電子分光シグナルは2次元周波数マップ として視覚化して議論される。通常は $t_{1}$ と $t_{3}$ に関する Fourier変換がなされる。電子励起状態におけるダイナミ クスを議論するために $t_{2}$ は時間のままで扱うのが良い：

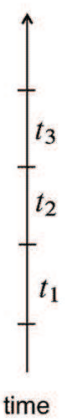

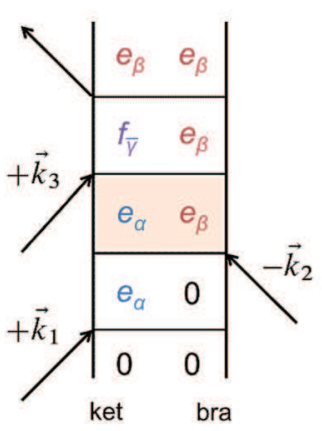

b

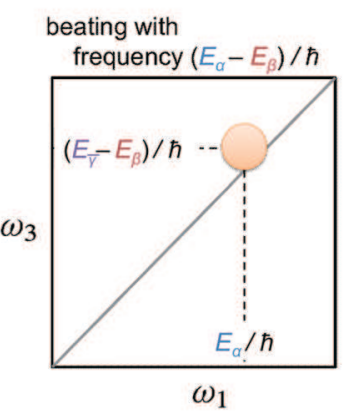

Fig. 3 (a) A double-sided Feynman diagram, which represent optical responses giving rise to quantum beats of $2 \mathrm{D}$ electronic spectra. In addition to 0 and $e_{\alpha}$ in Fig. $2, f_{\bar{\gamma}}$ represents an exciton state in the two-excitation manifold, where the number of excitons is two. The electronic system is also prepared in a coherence state, $\left|e_{\alpha}\right\rangle\left\langle e_{\beta}\right|$, during the waiting period $t_{2}$. As shown in panel (b), this process is observed as the beating of a peak $\left(\omega_{1}, \omega_{3}\right)=\left(E_{\bar{\gamma}}-E_{\alpha}, E_{\alpha}\right) / \hbar$ around the diagonal in $2 \mathrm{D}$ non-rephasing spectrum with a frequency of $\left(E_{\alpha}-E_{\beta}\right) / \hbar$.

$S_{\mathrm{NR}}\left(\omega_{3}, t_{2}, \omega_{1}\right)=\int_{0}^{\infty} d t_{3} \exp \left(i \omega_{3} t_{3}\right) \int_{0}^{\infty} d t_{1} \exp \left(i \omega_{1} t_{1}\right) S_{\mathrm{NR}}\left(t_{3}, t_{2}, t_{1}\right)(3.7)$

二次元周波数空間では, (3.5) 式またはFig. 2に示した過 程は $\left(\omega_{1}, \omega_{3}\right)=\left(E_{\alpha} / \hbar, E_{\alpha} / \hbar\right)$ の位置にピークとして現れ る。特に $\alpha \neq \beta$ はエキシトン間の量子力学的重ね合わせ の生成を意味するが, その存在はFig. 2 (b) とFig. 3 (b) に示したように対角線上に位置するピーク $\left(\omega_{1}, \omega_{3}\right)=$ $\left(E_{\alpha} / \hbar, E_{\alpha} / \hbar\right)$ または対角線近傍に位置するピーク $\left(\omega_{1}, \omega_{3}\right)=\left(E_{\bar{\gamma}}-E_{\beta} / \hbar, E_{\alpha} / \hbar\right)$ のコヒーレントな振動として 観測される.

Fig. 4に, Calhounらが温度77 KのLHCII (Fig. 1)に対し て得た二次元non-rephasing電子スペクトル $\left(t_{2}=250 \mathrm{fs}\right)$ (a)とその対角線に沿ったスペクトル (diagonal cut)の時 間発展(b)を示す ${ }^{9)} . \omega_{1}=\omega_{3}=15,000 \mathrm{~cm}^{-1}$ 付近の信号は $\mathrm{Chl} a$ 由来であり, 対して $\omega_{1}=\omega_{3}=15,500 \mathrm{~cm}^{-1}$ 付近の信号 はChlbによるものである. $t_{2}$ 軸に沿って, 二次元nonrephasing電子スペクトルの信号が少なくとも500フェム 卜秒は続いていることが分かる。第1節で述べた緑色硫 黄細菌に存在するFenna-Mathews-Olson夕ンパク質の結 果同様, このような長寿命は驚きと懷疑をもって受け止 められた。一方で, IshizakiとFlemingは光合成捕集タン パク質が電子状態に及ぼす摇らぎの時間スケールの有限 性を適切に考慮すれば，それらを無視してきた従来の理 論的枠組みよりも数倍長いコヒーレンスの寿命が得られ る事を示し, 天然の光合成光捕集系に対応するパラメー 夕領域では観測された量子コヒーレンスの寿命は実現し 得ることを理論的に示した ${ }^{15,16)}$.

二次元電子分光法を用いた光合成光捕集系における電 子励起の量子コヒーレンスの実験観測は，初期の段階に おいてはサンプルの温度調整に関する技術的困難もあり 
a

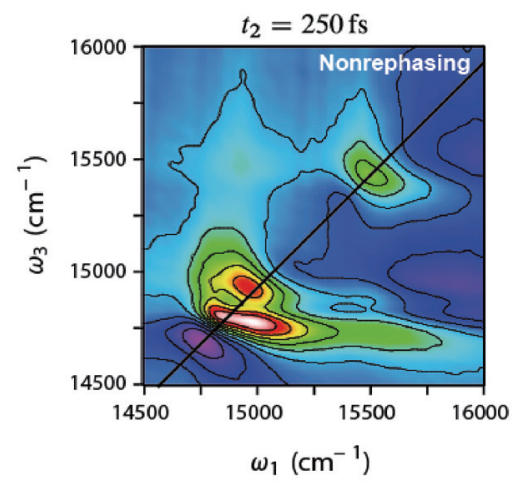

b

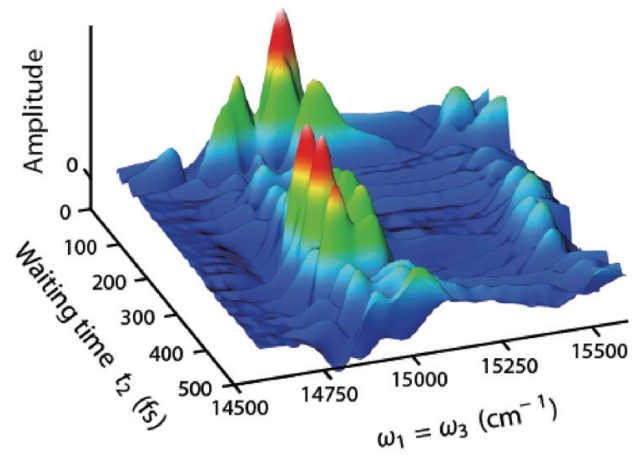

Fig. 4 (a) The real part of the 2D nonrephasing spectrum of light-harvesting complex II (LHCII) at the waiting time $t_{2}=250 \mathrm{fs}$ at $77 \mathrm{~K}^{9)}$. (b) Timeevolution of the amplitude of the diagonal cut (black diagonal line in panel a) of the 2D nonrephasing spectra as a function of waiting time $t_{2}{ }^{9)}$. Beating due to electronic coherence is evident in both Chl $a$ region $\left(\omega_{1}=\omega_{3} \sim 15,000 \mathrm{~cm}^{-1}\right)$ and Chl $b$ region $\left(\omega_{1}=\omega_{3} \sim 15,500 \mathrm{~cm}^{-1}\right)$.

温度77 Kで行われた。 しかし, 天然の光合成光捕集は常 温または生理的温度で行われている. IshizakiとFleming は生理的温度では350フェムト秒程度の量子コヒーレン スの寿命が可能であることを理論的に予測した。ほぼ同 時にシカゴ大学Engelのグループが緑色硫黄細菌の Fenna-Matthews-Olson色素タンパク質複合体に対して ${ }^{17)}$, またトロント大学のScholesのグループが海藻の一種で あるクリプト藻の光捕集色素タンパク質複合体 ${ }^{7}$ に対し て生理的温度における二次元電子分光実験に成功し, 理 論予測と整合する300フェムト秒程度の寿命を観測し た。

\section{4. まとめと展望}

本稿では, 光合成光捕集系研究の最近の展開, とくに 二次元電子分光法によって明らかにされた電子励起エネ ルギー移動と量子コヒーレンスに関する研究の一部を紹 介した，近年相次いで見出されている電子励起由来の長 寿命量子コヒーレンスは, 光合成光捕集の高い量子収率 に量子効果が何らかの役割を果たしているのではないか という希望的観測を研究者に抱かせ欧米を中心に大きな 注目を集めた。また, 著名な量子情報物理の研究者が相 次いで光合成エネルギー移動の研究に参入した。欧米の 一部ではquantum biologyという言葉が持ち入れられなが ら活発な研究領域に発展している。（1961年のLonguetHigginsの講演をうけ19)，日本では1965年には既に quantum biologyという言葉が用いられていたようであ る ${ }^{20)}$. ) 本最終節では国際的な研究動向・今後の発展性を 述べなければならないのであるが，筆者単独で関連分野 全体を隈無く公平に述べるのは望むべくもないので，こ こでは筆者個人の展望を述べたい.

\section{1 量子効果が重要なのか?}

2007年にFlemingグループが緑色硫黄細菌の光合成で 重要な役割を果たすFenna-Matthews-Olsonタンパク質内 の色素電子励起由来の長寿命量子コヒーレンスを報告し て以来，他の光合成光捕集タンパク質における長寿命量 子コヒーレンスの存在が報告された。 また数多くの理論 研究がなされ, 量子コヒーレンスと卓越した電子励起エ ネルギー移動効率との間に相関が見出された。しかし, そのような相関から「量子効果・量子コヒーレンスは重 要である」と主張するのは些か乱暴な議論であるように 思う。「色素の電子励起由来の量子コヒーレンスを長寿 命たらしめるタンパク質環境の性質・様態が電子励起エ ネルギー移動の効率の高さをもたらす」という議論も可 能なはずである。色素電子励起の長寿命量子コヒーレン スは夕ンパク質環境の様態に関する何らかの情報を示唆 しているのでは無いだろうか。量子効果に関する派手や かな議論だけではなく，光捕獲系における電子励起を好 ましい方向に効率よく進行させるには電子励起とそのダ イナミクスそしてそれを取り巻く局所的なタンパク質環 境がどうあるべきかという点について質実剛健な議論が 求められる.

\section{2 レーザーパルスと太陽光？}

2007年の最初の報告以来, 現在に至るまで最も強い批 判の一つが, レーザーパルスと太陽光の違いに関するも のである ${ }^{21)}$. 二次元電子分光法は数十フェムト秒程度の コヒーレントな超短パルス電場を用いることで，巨視的 なサンプル中に含まれた色素タンパク質複合体を一斉に 励起した結果として，量子コヒーレンスを観測した。一 方, 天然の条件下での色素タンパク質複合体の励起はイ ンコヒーレントな太陽光または他の色素タンパク質複合 体からのインコヒーレントはエネルギー移動によるもの である。（2.2節で述べたように，晴天時に緑色植物内の 色素分子が吸収する太陽光フォトンの数は1秒間あたり 約10個程度である ${ }^{1)}$.) 常々批判されるように，そのよう な条件では我々の目に見える量子ビートを観測する事は 難しいだろう。量子ビート・量子コヒーレンスそのもの が光合成光捕集系における卓越した量子収率を生み出す と考える場合，この「レーザーパルスvs太陽光」の問題は 困難な問題である。しかし，前節で述べたように色素の 電子励起由来の量子コヒーレンスを長寿命たらしめる夕 ンパク質環境の性質・様態が電子励起エネルギー移動の 効率の高さをもたらすと考える場合はどうであろうか.

しかし，この「レーザーパルス $\mathrm{vs}$ 太陽光」の疑問・批判 
は, 「分子アンサンブルの振る舞いvs単一分子の振る舞 い」という概念的にも実験技術的にも興味深い問いを 我々に突きつける ${ }^{22)}$. 光合成系における電子励起移動の 実験研究に限らず超高速分子分光実験は巨視的な分子ア ンサンブルにレーザーパルスを照射することでなされ， 巨視的なサンプル中に含まれた色素タンパク質複合体を 一斉に励起することで量子コヒーレンスを創り出す。さ らに，サンプルに含まれるそれぞれの色素タンパク質複 合体内の量子ビートそれぞれが局所的な摇らぎによって 乱された結果として量子ビート間のdistractive interferenceが観測で得られる量子コヒーレンスの観測可 能な寿命を与える。それでは, 各々の色素タンパク質複 合体内に打りる量子コヒーレンスはどのように振る舞つ ているのであろうか? 天然の光合成光捕獲では一つの色 素タンパク質複合体が一つの太陽光フォトンを吸収する ことで電子励起エネルギー移動が誘起される，スペイン ICFOのvan Hulstのグループが, phase-locked spontaneous light emissionに基づいて単一分子における振動コヒーレ ンスや電子コヒーレンスの実験観測の取り組みを始めて いる ${ }^{23,24)}$. 光合成光捕集系に拈ける高効率エネルギー移 動の理解に本質でないかもしれないが, デコヒーレンス の理解に関係する量子力学の基本問題としても興味深い 方向であるように思う。また，従来の分子アンサンブル の振る舞いに基づくトップダウン的アプローチと分子描 像に基づいた微視的立場から統計的振る舞いの再現を試 みるボトムアップ的アプローチを橋渡しする概念や方法 論の確立が求められる.

\section{3 光合成光捕集は常に効率が良いのか?}

「生物系における量子効果」のサブジェクトとして光合 成光捕集系が取り上げられる場合，おおよそエネルギー 移動・変換の効率の良さに話が限定される。しかし, 色 素分子の光吸収によって生じる電子励起エネルギーが反 応中心において電荷分離反応に用いられる量子収率がほ ぼ100\%という状況は，太陽光が比較的弱い場合にのみ 言えることである. 強光下に曝された場合には, 長寿命 のカチオンまたは一重項酸素の生成などによるタンパク 質の損傷を防御するために，過㮃に生じた電子励起エネ ルギーは熱として捨てられる。このような自己防衛のた めの調整機構にとって量子効果は無関係かもしれない. しかし, 太陽光強度の強弱に応じて自律的に発現する 「卓越した効率で起こる電子励起エネルギー移動」と「励 起エネルギーを熱放出させる調整機構」という一見相反 する二つのダイナックな過程のスイッチング機構がどの ような分子過程がトリガーとなりどのような分子過程を 経て引き起こされるのかという分子世界の階層性を跨い
だ因果関係を理解したい。レーザー分光実験と理論物理 化学研究の更なる協奏的研究が望まれる.

\section{謝 辞}

I was a fellow at Wissenschaftskolleg zu Berlin (WIKO) while the manuscript was prepared. I would like to acknowledge WIKO for the hospitality.

\section{参考文献}

1) R. E. Blankenship: Molecular Mechanisms of Photosynthesis (World Scientific, London, 2002).

2) H. van Amerongen, L. Valkunas, and R. van Grondelle: Photosynthetic Excitons (World Scientific, Singapore, 2000).

3) T. Brixner, J. Stenger, H. M. Vaswani, M. Cho, R. E. Blankenship, and G. R. Fleming: Nature 434 (2005) 625.

4) G. S. Engel, T. R. Calhoun, E. L. Read, T. K. Ahn, T. Mančal, Y. C. Cheng, R. E. Blankenship, and G. R. Fleming: Nature 446 (2007) 782.

5) H. Lee, Y. C. Cheng, and G. R. Fleming: Science 316 (2007) 1462.

6) S. Westenhoff, D. Paleček, P. Edlund, P. Smith, and D. Zigmantas: J. Am. Chem. Soc. 134 (2012) 16484.

7) E. Collini, C. Y. Wong, K. E. Wilk, P. M. G. Curmi, P. Brumer, and G. D. Scholes: Nature 463 (2010) 644.

8) T. R. Calhoun, N. S. Ginsberg, G. S. Schlau-Cohen, Y.-C. Cheng, M. Ballottari, R. Bassi, and G. R. Fleming: J. Phys. Chem. 113 (2009) 16291

9) G. S. Schlau-Cohen, A. Ishizaki, T. R. Calhoun, N. S. Ginsberg, M. Ballottari, R. Bassi, and G. R. Fleming: Nat. Chem. 4 (2012) 389.

10) S. Mukamel: Principles of Nonlinear Optical Spectroscopy (Oxford University Press, 1995).

11) A. Ishizaki, T. R. Calhoun, G. S. Schau-Cohen, G. R. Fleming: Phys. Chem. Chem. Phys. 12 (2010) 7319.

12) G. S. Schlau-Cohen, A. Ishizaki, and G. R. Fleming: Chem. Phys. 386 (2011) 1.

13) 田原太平：レーザー研究 32 (2004) 687.

14）竹内 佐年, 田原太平：レーザー研究 40 (2012) 759.

15) A. Ishizaki and G. R. Fleming: J. Chem. Phys. 130 (2009) 234111.

16) A. Ishizaki and G. R. Fleming: Proc. Natl. Acad. Sci. USA 106 (2009) 17255 .

17) G. Panitchayangkoon, D. Hayes, K. A. Fransted, J. R. Caram, E. Harel, J. Wen, R. E. Blankenship, and G. S. Engel: Proc. Natl. Acad. Sci. USA 107 (2010) 12766.

18) A. Ishizaki and G. R. Fleming: Annu. Rev. Condens. Matter Phys. 3 (2012) 333.

19) H. C. Longuet-Higgins: Biophys. J. 2 (1962) 207.

20) 寺本英, 福留秀雄, 右衛門佐 重雄, 大沢文夫：物性研 究 4 (1965) 376.

21) P. Brumer and M. Shapiro: Proc. Natl. Acad. Sci. USA 109 (2012) 19575.

22) A. Ishizaki and G. R. Fleming: J. Phys. Chem. B 115 (2011) 6227.

23) D. Brinks, F. D. Stefani, F. Kulzer, R. Hildner, T. H. Taminiau, Y. Avlasevich, K. Mullen, and N. F. van Hulst: Nature 465 (2010) 905.

24) R. Hildner, D. Brinks, and N.F. van Hulst: Nature Phys. 7 (2011) 172 . 